\title{
Persepsi wisatawan terhadap kuliner lokal pada hotel berbintang di kabupaten badung
}

\author{
Ni Made Ariani ${ }^{1)}$, Ni Nyoman Sri Aryanti ${ }^{2)}$ \\ Program Studi Diploma IV Pariwisa ta, Fakultas Pariwisata, Universitas Udayana ${ }^{12)}$ \\ Email:ayukariani97@yahoo.com, sriaryanti@unud.ac.id
}

\begin{abstract}
Abstrak
Kabupaten Badung merupakan salah satu destinasi wisata di Bali. Letak daerah ini sangat stra tegis yang merupakan akses wisata ke Kuta Selatan, Kuta dan ke Bandara Internasional Ngurah Rai. Daerah ini juga dilengkapi dengan sarana kepariwisata an yang dibutuhkan oleh wisatawan ketika berwisa ta meliputi restoran, akomodasi dan souvenir.Kajian penelitian ini difokuskan pada restoran merupakan suatu usaha komersial yang menyediakan jasa pelayanan makan dan minum bagi umum dan dikelola secara professional. Kebera daan restoran sebagai salah satu sarana penting dalam kegiatan pariwisa ta ada yang berdiri sendini dan ada yang menjadi satu dengan lingkungan hotel. Restoran yang di kaji adalah restoran yang terdapat di dalam lingkungan hotel dan menyediakan kuliner lokal sebagai daya tarik bagi wisa tawan yang menginap pada hotel berbintang di Kabupaten Badung. Beragamn yarestoran yang tumbuh dan berkembang saat ini perlu kiranyauntuk men gidentifikasi persepsi wisa tawan terhadap adaptasi ku liner lokal tersebut. Penelitia n inidilaksanakan melalui kajian deskriptif interpretatif dan kualitatif yang bertujuan untuk mengidentifikasikan kulin er lokal dari a s pek perse psi. Penyajian hasilyang diuraikan secara Kualitatif dan Kuantitatif, dengan demikian akan diperoleh gambaran yang lebih jelas dan mendalam tentang penelitian yang dilakukan. Berdasarkan hasil penelitia n diperoleh hasil bahwa persepsi wisa tawan terhadap kuliner lokal yang ditawarkan pada hotelberbintang di Kabupaten Badung dengan katagori baik yang ditunjukkan dengan skor rata-rata 3,70. Hal ini dilihat dari aspek penampilan dalam penyajian, kualitas produk, kesesuian harga, variasi menu dan kualitas pelayanan. Adapun indika tor kualitas pelayanan mendapatkan skor tertinggi sebesar 4.45 yang berarti sangat baik, ka rena kualitas pela yanan dalam usaha hospitality merupakan kunci utama bagi perusahaan jasa untuk mewujudkan kepuasan dari wisata wan. Va riasi menu yang ditawarkan merupakan indikator dengan skor terrendah sebesar 2,65 yang artinya kuliner lokal yang ditawarkan memiliki variasi menu yang kurang beranekaragam sehingga wisatawan sulit untuk melakukan pemilihan terhadap kuliner lokal yang ditawarkan.
\end{abstract}

Kata Kunci :KulinerLokal, Wisa tawan, Restoran

\begin{abstract}
Badung Regency is one of the tourist destinations in Bali. The location of this a rea is very strategic which is a tourist access to South Kuta, Kuta and to Ngurah Rai International Airport. This a rea is a lso equipped with tounism facilities needed by tourists when traveling, including restaurants, accommodation and souvenirs. This research study focuses on the restaurant is a commercial business that provides food and drink services for the public and is managed professionally. The ex istence of a restaurant as an important means of tourism activities is independent and some are integrated with the hotelenvironment. The restaurant that is being reviewed is a resta urant located within the hotel environment and provides local culinary as an attraction for tourists staying at star hotels in Badung Regency. The variety of restaurants that are growing and developing today is necessary to identify tourists' perceptions of the localculinary a daptation. This research was conducted through an interpretive and qualitative descriptive study which aims to identify local culinary from the perceptual aspect. Presentation of the results described qualitatively and quantitatively, thereby obtaining a clearer a nd deeper picture of the research carried out. Based on the results of the research, it is found that the perception of tourists toward local culinary offered at star hotels in Badung Regency is in a good ca tegory a s indicated by an a verage score of 3.70. This can be seen from the aspect of appearance in presentation, product quality, price suitability, menu variations and service quality. The service quality indicator gets the highest score of 4.45 which mea ns very good, because the quality of service in the hospitality business is the main key for service companies to rea lize the satisfaction of tourists. The menu variation offered is an indicator with the lowest score of 2.65 , which means that the local culinary offered has a less diverse menu so tourists find it difficult to make choices about the local culinary offered.
\end{abstract}

Keywords: Local Culinary, Tourist, Restaurant 


\section{PENDAHULUAN}

Pada jaman era globalisasi ini, pariwisata sebagai suatu komoditas yang dibutuhkan oleh hampir setiap individu, dengan melaksanakan aktivitas kepariwisataan dapat meningkatkan daya kreativitas, mengurangi tingkat kejenuhan dalam bekerja, membuka wawasan mengenai budaya suatu daerah, relaksasi, mengetahui peninggalan yang berhubungan dari suatu bangsa, serta melakukan bisnis (Wiyasa, 1997). Selain itu, pariwisata sangat berpengaruh terhadap penerimaan negara melalui devisa dan pajak, di samping itu juga berpengaruh terhadap peningkatan pendapatan penduduk setempat (Widoyono,2006). Perkembangan industri pariwisata di Indonesia sendiri didukung oleh berbagai potensi pariwisata. Objek pariwisata yang sangat beragam menyerap banyak wisatawan baik domestik maupun asing untuk mengunjunginya. Seiring dengan peningkatan kunjungan wisatawan di Indonesia harus juga diimbangi dengan peningkatan sarana prasarana penunjang kepariwisataan. Salah satu sarana penunjang yang dibutuhkan wisatawan ketika melakukan kegiatan wisata yaitu industri jasa yang bergerak dibidang makanan dan minuman atau lebih dikenal dengan nama restoran. Restoran sebagai suatu usaha komersial yang menyediakan jasa pelayanan makan dan minum bagi umum dan dikelola secara professional dan keberadaan restoran sebagai salah satu sarana penting dalam kegiatan pariwisata ada yang berdiri sendiri dan ada pula yang menjadi satu dengan lingkungan hotel. Beragamnya restoran yang tumbuh dan berkembang saat ini perlu kiranya untuk mengidentifikasi klasifikasi dari restoran tersebut serta hidangan yang ditawarkan.

Keberagaman restoran yang berkembang disuatu destinasi wisata merupakan pilihan yang sulit bagi wisatawan untuk melakukan pembelian terhadap produk yang ditawarkan oleh berbagai restoran yang berada di suatu destinasi tersebut. Menurut Pendit (2002: 100), seni kuliner merupakan salah satu daya tarik bagi wisatawan mancanegara untuk mengadakan perjalanan dengan harapan dapat makan enak,minum enak dan tidur nyenyak. Lebih lanjut wisata kuliner merupakan industri untuk menyediakan makanan bagi wisatawan dari negara, wilayah atau daerah, tujuan wisata dan sekarang dianggap sebagai komponen penting dalam industri pariwisata. Disamping itu wisata kuliner menyangkut semua pengalaman yang berhubungan dengan makanan dan minuman khas negara atau daerah yang unik dan mengesankan, mulai dari bahan dan bumbu yang digunakan, cara pengolahan, dan juga cara penyajian. Wisata kuliner mempunyai peranan penting dalam kegiatan wisata karena hampir semua wisatawan makan di luar selama melakukan kegiatan wisata, aktivitas makan merupakan aktivitas yang digemari oleh wisatawan. Jika dilihat dari sisi tagihan dapat dilihat bahwa kemungkinan besar dihabiskan untuk kebutuhan makan dan minum dengan masakan lokal merupakan salah satu pendorong dalam memilih suatu destinasi wisata (Trisna,2013)

Usaha restoran yang dikaji dalam penelitian ini adalah restoran yang menjadi satu dengan lingkungan hotel yang tersebar pada hotel berbintang di Kabupaten Badung. Restoran yang terdapat di sebuah hotel memiliki berbagai tife restoran dengan menu yang ditawarkan yang beragam. Kajian ini lebih difokuskan pada menu dengan kuliner lokalnya karena kuliner lokal ini memiliki daya tarik tersendiri untuk dicoba oleh wisatawan yang berkunjung ke Bali.

Pola perilaku wisatawan dalam memilih kuliner lokal yang ditawarkan pada hotel berbintang di Kabupten Badung merupakan pengambilan keputusan wisatawan untuk melakukan wisata kulinernya, karena wisatawan akan melakukan pembelian atau tidak melakukan pembelian. Konsep tentang pengambilan keputusan konsumen telah menjadi bahasan penelitian terkait dengan perilaku konsumen. Model ini diawali dengan munculnya kebutuhan wisatawan terhadap produk yang akan dibelinya atau dikunjunginya. Ini merupakan hal penting untuk dikaji sehingga kita dapat menyediakan produk sesuai dengan kebutuhan wisatawan sehingga produk yang disediakan akan diadaptasikan mengikuti kebutuhan dari wisatawan sebagai pangsa pasar pembelinya.

Berkaitan dengan konsep tersebut maka pada penelitian ini akan mengkaji tentang Kuliner Lokal sebagai daya tarik Pada Hotel Berbintang di Kabupaten Badung. Hal ini menarik untuk dikaji dan diteliti sebagai suatu objek penelitian yang bersifat akademis. Oleh karena itu dari penelitian ini diharapkan dapat menghasilkan suatu kajian yang memperlihatkan Persepsi Wisatawan terhadap kuliner lokal tersebut. Berdasarkan pada uraian latar belakang diatas maka rumusan masalah yang akan diteliti yaitu : Bagaimanakah persepsi wisatawan terhadap adaptasi kuliner lokal pada Hotel Berbintang di Kabupaten Badung. Adapun tujuan yang ingin dicapai pada penelitian ini adalah Untuk 
mengetahui persepsi wisatawan terhadap adaptasi kuliner lokal pada Hotel Berbintang di Kabupaten Badung.

\section{METODE PENELITIAN}

Rancangan penelitian yang digunakan adalah penggabungan antara kuantitatif sertakualitatif. Penelitian ini berfokus pada pendekatan observasi, pengumpulan data dengan cara melaukakn wawancara dan pennyebaran kuisioner. Pada penelitian ini juga memakai pendekatan deskriptif analisis dengan titik perhatian pada penelitian perilaku wisatawan yang dalam konteks pariwisata sebagai daya tarik pariwisata yang dilihat dari persepsi wisatawan terhadap kuliner lokal pada hotel berbintang di Kabupaten Badung. Penelitian ini jenis dan sumber data diperoleh secara langsung dari lokasi penelitian yang menjadi subjek penelitian. Data-data yang diperoleh akan sangat membantu dalam memecahkan permasalahan yang di teliti sehingga akan didapatkan informasi penelitian yang lebih akurat di dalam penulisannya. Bila dilihat dari teknik pengumpulan data, maka teknik pengumpulan data dapat dilakukan dengan cara observasi (pengamatan), interview (wawancara), kuesioner (angket), dokumentasi dan gabungan keempatnya (Sugiyono, 2006: 62-63). Penentuan informan dilakukan dengan metode purpose sampling, adalah teknik penentuan sampel dengan pertimbangan tertentu dan dipandang mempunyai pengetahuan dan kemampuan dengan permasalahan, serta dengan kriteria tertentu yang telah diterapkan berdasarkan tujuan penelitian (Sugiyono, 2004).

Penentuan informan dilakukan dengan memilih restoran yang menyediakan kuliner lokal yang tersebar pada hotekl berbintang di Kabupaten Badung ditentukan berdasarkan metode purposive sampling. Artinya, pemilihan restoran yang dianggap sesuai dengan topik penelitian berdasarkan pengetahuan dan pertimbangan tertentu dari penelitian, misalnya kesediaan waktu dan tenaga termasuk kemudahan dalam mendapatkan data, berdasarkan ketentuan tersebut terdapat 2 buah restoran. Analisis dalam penelitian ini adalah analisis deskriptif kualitatif, ini diartikan sebagai metode dengan memberikan ulasan atau interpretasi terhadap data dan informasi yang diperoleh, sehingga menjadi lebih bermakna, meskipun demikian penelitian ini juga didukung dengan data kuantitatif dengan nilai kuisioner yang diperoleh dengan skala likert.

\section{HASIL DAN PEMBAHASAN}

\subsection{Hasil}

\section{Karakteristik Responden}

Responden yang digunakan sebagai populasi adalah wisatawan mancanegara dan domestik yang dikatagorikan sebagai wisatawan dengan permintaan yang efektif atau actual yang berarti wisatawan yang sedang melakukan perjalanan wisata di Bali yang tersebar di berbagai destinasi wisata yang ada di Bali. Jumlah sampel adalah 100 orang wisatawan mancanegara yang diperoleh dengan teknik Quota Sampling yang mengacu pada pendapat J. Suprianto dengan pertimbangan jumlah indikator dikalikan 5. Responden yang dijadikan sampel dicari dengan accidental sampling melalui penyebaran kuisioner.

Karakteristik responden ini terdiri dari kebangsaan yang merupakan daerah asal dari wisatawan, status, jenis kelamin,usia, pekerjaan dan tingkat pendidikan. Berdasarkan karakteristik tersebut secara lebih jelas dapat dilihat pada Tabel 1 berikut :

\section{Tabel 1 Karakteristik Responden}

\begin{tabular}{|c|c|c|c|}
\hline \multirow[b]{2}{*}{ No } & \multicolumn{3}{|c|}{ Jumlah } \\
\hline & Karakteristik Responden & Orang & Kontribusi (\%) \\
\hline & Berdasarkan Negara Asal (Benua) & & \\
\hline 1 & Amerika & 5 & 5,00 \\
\hline 2 & Eropa & 10 & 10,00 \\
\hline 3. & Australia & 30 & 30,00 \\
\hline 4. & Asia & 55 & 55,00 \\
\hline
\end{tabular}




\begin{tabular}{|c|c|c|c|}
\hline & & 100 & 100,00 \\
\hline & Status & & \\
\hline 1. & Menikah & 40 & 40,00 \\
\hline 2. & Belum Menikah & 60 & 60,00 \\
\hline \multirow[t]{3}{*}{3.} & Duda/Janda & 0 & 0,00 \\
\hline & & 100 & 100,00 \\
\hline & Jenis Kelamin & & \\
\hline 1. & Pria & 55 & 55,00 \\
\hline \multirow[t]{2}{*}{2.} & Wanita & 45 & 44,00 \\
\hline & & 100 & 100,00 \\
\hline 1. & Pekerjaan & & \\
\hline 2. & Student & 40 & 40,00 \\
\hline 3. & Policy & 1 & 1,00 \\
\hline 4. & Private employee & 20 & 20,00 \\
\hline 5. & Pensioner & 0 & 0,00 \\
\hline 6. & Civil Servant & 5 & 5,00 \\
\hline 7. & Profesional & 24 & 24,00 \\
\hline 8. & Businessman & 10 & 10,00 \\
\hline \multirow[t]{3}{*}{9.} & Other & 0 & 0.00 \\
\hline & & 100 & 100,00 \\
\hline & Tingkat Pendidikan & & \\
\hline 1. & Elementary & 0 & 0,00 \\
\hline 2. & High School & 14 & 14,00 \\
\hline 3. & Diploma & 22 & 22,00 \\
\hline 4. & Undergraduate & 40 & 40,00 \\
\hline 5. & Master & 20 & 20.00 \\
\hline 6. & Doctoral & 4 & 4,00 \\
\hline \multirow[t]{2}{*}{7.} & Other & 0 & 0,00 \\
\hline & & 100 & 100 \\
\hline
\end{tabular}

Sumber : Hasil Penelitian (2019)

Berdasarkan pada Tabel 1 tentang karakteristik responden dapat dilihat berdasarkan katagori asal wisatawan, status, jenis kelamin, pekerjaan dan tingkat pendidikan wisatawan yang melakukan wisata dengan kuliner lokal yang ditawarkan oleh hotel berbintang di Kabupaten Badung dengan rincian sebagai berikut berdasarkan daerah asal wisatawan di dominasi dari Asia seperti kita ketahui pada saat ini pangsa Asia menjadi pangsa pasar yang ditargetkan oleh pemerintahan Indonesia dan Bali pada khususnya. Pada aspek status didominasi oleh wisatawan dengan status tidak menikah dengan jenis kelamin laki-laki dan pekerjaan wisatawannya sebagian besar sebagai student dengan tingkat pendidikan didominasi undergraduate. Hal ini erat sekali hubungannya dengan status wisatawan yang melakukan wisata kuliner lokal adalah tidak menikah.

\section{Persepsi Wisatawan Terhadap Adaptasi Kuliner Lokal Pada Hotel Berbintang di Kabupaten Badung}

Adaptasi kuliner lokal yang ditawarkan oleh hotel berbintang di Kabupaten Badung dipersepsikan oleh wisatawan yang pernah mencicipi hidangan kuliner lokal. Adapun hal-hal yang dipersepsikan terkait dengan adaptasi kuliner lokal tersebut meliputi :

1. Aspek kualitas produk dengan indikator penampilan dalam penyajian, cita rasa dan aroma.

2. Aspek harga dengan sub indikator kesesuaian harga. 
3. Aspek menu yang ditawarkan dengan sub indikator variasi pilihan menu yang ditawarkan.

4. Aspek pelayanan dengan sub indikator pelayanan yang diberikan oleh pramusaji.

Berdasarkan hasil penyebaran kuisioner terhadap 100 wisatawan dapat diperoleh data seperti yang tersaji pada Gambar 3.1 berikut:



Gambar 3.1 Persepsi Wisatawan terhadap Adaptasi kuliner lokal (aspek penampilan dalam penyajiannya) Sumber : Hasil penelitian (2019)

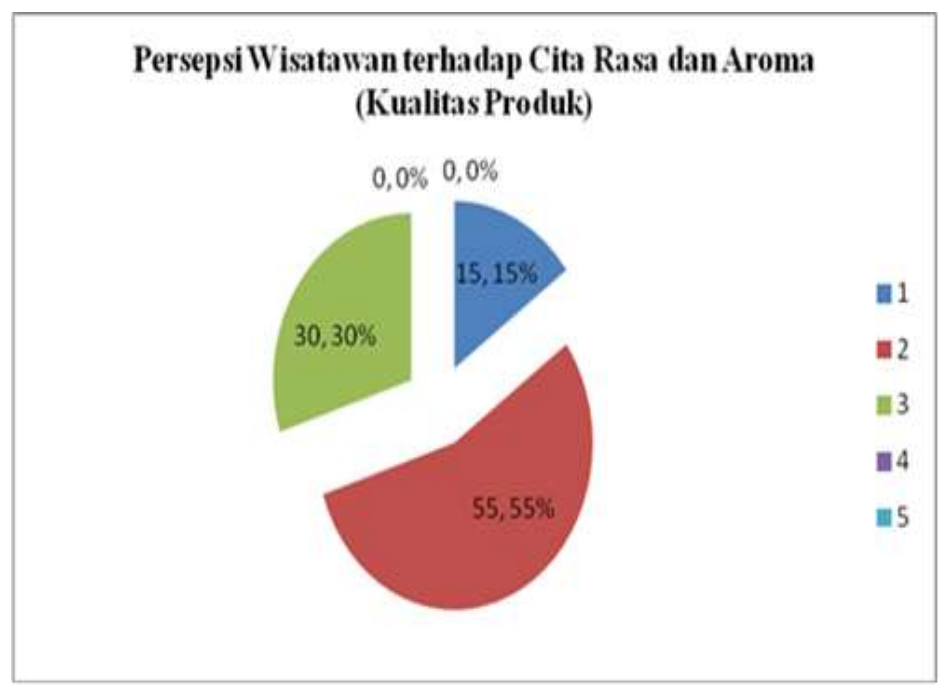

Gambar 3.2 Persepsi Wisatawan terhadap Adaptasi kuliner lokal (aspek Cita Rasa dan Aroma) Sumber : Hasil Penelitian (2019)

Berdasarkan pada aspek penampilan dalam penyajiannya kuliner lokal yang disajikan pada hotel berbintang di Kabupaten Badung. Adaptasi kuliner lokal tersebut dipersepsikan oleh wisatawan dengan katagori baik dengan jumlah jawaban respoden 55 orang dengan prosentase $55 \%$. Hal ini menunjukkan bahwa wisatawan tertarik dengan penampilan kuliner lokal ketika disajikan kepada wisatawan walaupun masih terdapat penilaian cukup baik terhadap penampilan dalam penyajian.

Hasil persepsi wisatawan terhadap adaptasi kuliner lokal dilihat dari aspek cita rasa dan aroma di nilai baik oleh wisatawan dengan jumlah jawaban sebesar 55 orang. Penilaian cukup juga diberikan 
wisatawan terhadap cita rasa dan aroma dari kuliner lokal yang ditawarkan pada hotel berbintang di Kabupaten Badung dengan prosentase 30\% dari 100 responden yang memberikan jawaban. Hal ini secara keseluruhan jawaban wisatawan terhadap aspek cita rasa dan aroma masih dikatagorikan baik. Namun dikarenakan masih cukup besarnya jawaban cukup baik terhadap cita rasa dan aroma maka hotel berbintang yang terdapat di Kabupaten Badung diharapkan melakukan perbaikan dan peningkatan cita rasa dan aroma terhadap kuliner lokal yang disajikan dan ditawarkan kepada wisatawan dengan mengikuti keinginan wisatawan dengan kebudayaan yang dimiliki.

Kesesuaian harga sangat penting menjadi pertimbangan dalam keputusan pembelian terhadap suatu produk. Nilai uang yang dibayarkan biasanya diikuti dengan kualitas produk yang diberikan. Berdasarkan pada aspek kesesuaian harga persepsi wisatawan terhadap adaptasi kuliner lokal secara keseluruhan adalah baik dengan menyebarkan kuisioner kepada 100 wisatawan diperoleh jawaban baik sebesar 50\% dan 30\% dengan katagori cukup. Hal ini dapat dihubungkan dengan hasil motivasi wisatawan karena wisatawan yang melakukan wisata kuliner dengan kuliner lokal yang ditawarkan pada destinasi yang dikunjungi didominasi oleh rasa ingin tahu dan pengalaman yang ingin didapatkan.



Gambar 3.3 Persepsi Wisatawan terhadap Adaptasi kuliner lokal (aspek kesesuaian harga) Sumber : Hasil Penelitian (2019)

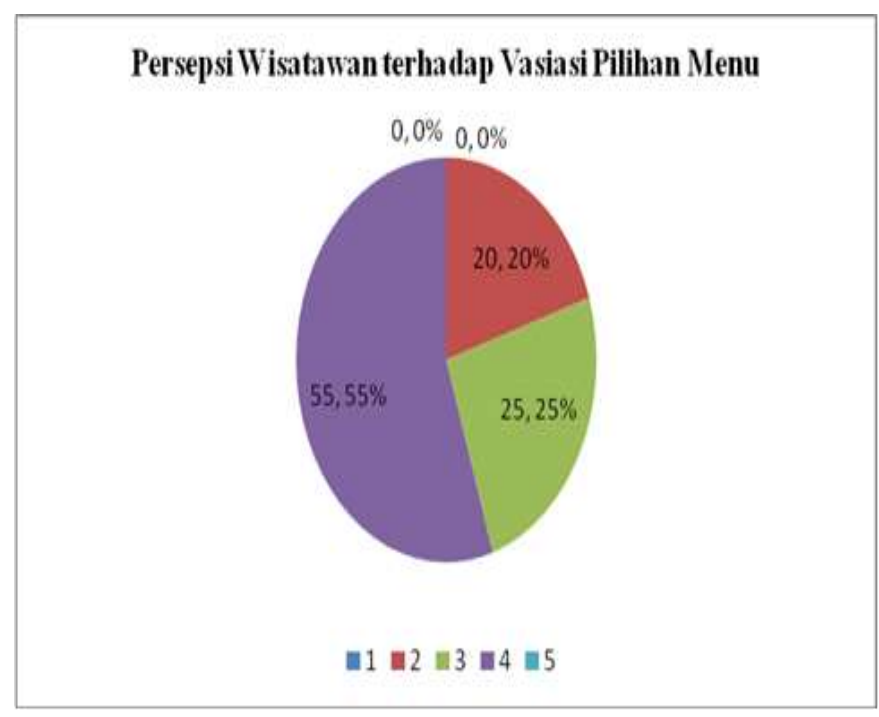

Gambar 3.4 Persepsi Wisatawan terhadap Adaptasi kuliner lokal (aspek variasi pilihan menu)

Sumber : Hasil Penelitian (2019) 
Pada aspek variasi pilihan menu kuliner lokal mendapatkan penilain dari wisatawan buruk dengan jumlah jawaban sebesar 55 orang responden yamg disusul dengan cukup sebesar 25 responden. Hal ini menunjukkan bahwa variasi pilihan terhadap kuliner lokal yang ditawarkan hotel berbintang di Kabupaten Badung sangat minim jumlahnya sehingga wisatawan tidak memiliki pilihan yang leluasa terhadap kuliner lokal tersebut. Persepsi ini juga didukung dengan hasil permasalahan no 2 pada penelitian ini dapat dilihat bahwa kuliner lokal yang ditawarkan oleh hotel berbintang di Kabupaten Badung masih sangat sedikit jumlah yang ditawarkan dengan jenis hidangan yang biasanya berlaku di sektor makanan baik sebagai hidangan pembuka, soup, hidangan utama ataupun sebagai hidangan penutup.

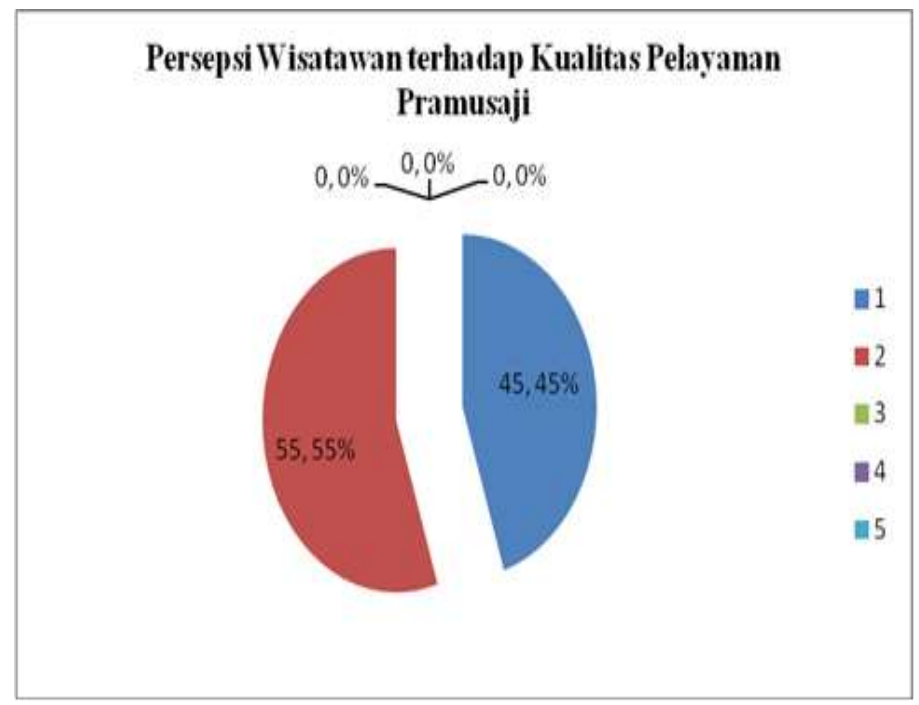

Gambar 3.5 Persepsi Wisatawan terhadap Adaptasi kuliner lokal (aspek kualitas pelay anan pramusaji) Sumber : Hasil Penelitian (2019)

Berdasarkan pada Tabel 3.5 dapat dilihat bahwa persepsi wisatawan terhadap adaptasi kuliner lokal terkait dengan aspek kualitas pelayanan pramusaji dapat dikatagorikan baik, karena sebagian besar respoden menjawab dengan pilihan baik sebesar 55\% dan jawaban sangat baik sebesar $45 \%$. Hal ini menunjukan keramahtamahan, sopan santun dan empaty karyawan di industri pariwisata merupakan penilaian yang dianggap baik oleh wisatawan dan aspek ini merupakan aspek penting ketika suatu destinasi wisata dikembangkan.

\subsection{Pembahasan}

Berdasarkan pada uraian persepsi wisatawan terhadap kuliner lokal pada hotel berbintang di Kabupaten Badung secara lebih rinci dapat dilihat pada tabel berikut :

Tabel 2 Rekapitulasi Persepsi Wisa tawan terhadap Kuliner Lokal pa da Hotel Berbintang di Kabupaten Badung.

\begin{tabular}{|c|c|c|c|c|c|c|c|c|}
\hline \multirow[t]{2}{*}{ NO } & \multirow[t]{2}{*}{ Pernyataan } & \multicolumn{5}{|c|}{ Persepsi } & \multirow[t]{2}{*}{ Total } & \multirow{2}{*}{$\begin{array}{l}\text { Rata- } \\
\text { Rata }\end{array}$} \\
\hline & & 5 & 4 & 3 & 2 & 1 & & \\
\hline 1 & $\begin{array}{l}\text { Penampilan } \\
\text { dalam } \\
\text { penyajian }\end{array}$ & 20 & 55 & 25 & 0 & 0 & 395 & 3,95 \\
\hline 2 & $\begin{array}{l}\text { Kualitas } \\
\text { Produk }\end{array}$ & 15 & 55 & 30 & 0 & 0 & 385 & $\begin{array}{l}\text { Baik } \\
3,85\end{array}$ \\
\hline
\end{tabular}




\begin{tabular}{|c|c|c|c|c|c|c|c|c|}
\hline 3 & $\begin{array}{l}\text { Kesesuaian } \\
\text { Harga }\end{array}$ & 20 & 50 & 30 & 0 & 0 & 390 & 3,90 \\
\hline & & & & & & & & Baik \\
\hline \multirow[t]{2}{*}{4} & $\begin{array}{l}\text { Variasi } \\
\text { Menu }\end{array}$ & 0 & 20 & 25 & 55 & 0 & 265 & 2,65 \\
\hline & & & & & & & & $\begin{array}{l}\text { Cukup } \\
\text { Baik }\end{array}$ \\
\hline \multirow[t]{4}{*}{5} & $\begin{array}{l}\text { Kualitas } \\
\text { Pelayanan }\end{array}$ & 45 & 55 & 15 & 0 & 0 & 445 & 4,45 \\
\hline & & & & & & & & $\begin{array}{l}\text { Sangat } \\
\text { Baik }\end{array}$ \\
\hline & $\begin{array}{l}\text { Rata-rata } \\
\text { keseluruhan }\end{array}$ & & & & & & & 3,76 \\
\hline & & & & & & & & Baik \\
\hline
\end{tabular}

Sumber : Hasil Penelitian (2019)

Tabel 2 menunjukkan wisatawan mempersepsikan bahwa kuliner lokal yang ditawarkan oleh hotel berbintang di Kabupaten Badung jika dilihat dari aspek variasi menu yang ditawarakan masih berada dalam katagori cukup baik dengan skor rata-rata 2,65. Hal ini ditunjukkan oleh Tabel 3 seperti berikut

Tabel 3 Jenis Hidangan lokal yang Ditawarkan Hotel Berbintang di Kabupaten Badung No. Jenis Hidangan Lokal yang dita warkan

\begin{tabular}{|c|c|c|c|c|}
\hline & $\begin{array}{l}\text { Hidangan Pembuka } \\
\text { (Appertizer) }\end{array}$ & Soup & $\begin{array}{l}\text { Hidangan Utama } \\
\text { (MainCourse) }\end{array}$ & $\begin{array}{c}\text { Hidangan Penutup } \\
\text { (Dessert) }\end{array}$ \\
\hline 1 & Jukut Urap & Gerang Asem & Ayam Betutu & Jaja Klepon \\
\hline 2 & LawarNa ngka & Jukut Ares & BabiGuling & $\begin{array}{l}\text { Godoh (pisang } \\
\text { goreng) }\end{array}$ \\
\hline 3 & & Kuah Be Pasih & $\begin{array}{l}\text { Sate Lilit } \\
\text { Ikan/Ayam }\end{array}$ & Batun Bedil \\
\hline
\end{tabular}

$\begin{array}{ll}4 & \text { Pesan Be Pasih } \\ & \text { Be Pasih Sambel } \\ & \text { Matah }\end{array}$

Sumber: Hasil Penelitian(2019).

Ini berarti bahwa variasi pilihan menu kuliner lokal masih minim sehingga berdampak kepada keleluasaan wisatawan untuk memilih dan mencoba kuliner lokal yang ditawarkan pada hotel berbintang di Kabupaten Badung. Kualitas pelayanan dinilai oleh wisatawan sudah sangat baik dengan skor 4,45. Hal ini menunjukkan bahwa hospitality yang ditunjukkan oleh karyawan selama melakukan pelayan sudah menjadi ciri khas dalam dunia industri pariwisata.

Secara umum kuliner lokal yang ditawarkan oleh hotel berbintang di Kabupaten Badung disukai oleh kaum milenial dengan motivasi secara instrinsik karena dorongan rasa ingin tahu dan pengalaman dan pemilihan di Kabupaten Badung karena letaknya yang strategis. Hal ini dikarenakan kaum milenial leioh mudah mendapatkan informasi terkait dengan destinasi yang dikunjunginya karena mereka termasuk generasi yang cenderung familiar dengan teknologi informasi yang merupakan 
generasi yang tidak bias lepas dari internet dan gadget. Rekomendasi tidak berbayar ini kemudian menjadi referensi dan preferensi wisatawan lainnya untuk makan saat berlibur ke Bali dan mencari kuliner lokal sebagai daya tarik.

\section{KESIMPULAN}

Persepsi wisatawan terhadap adaptasi kuliner lokal pada hotel berbintang di Kabupaten Badung yang mendapat penilaian terrendah adalah variasi pilihan menu kuliner lokal yang ditawarkan dengan skor 2.65 dengan katagori cukup. jika dilihat dari aspek kulitas produk, kesesuain harga dengan katagori baik sedangkan untuk aspek kualitas pelayanan pramusaji mendapatkan skor dengan rata-rata 4,45 yang berarti sangat baik. Kuliner lokal yang ditawarkan oleh hotel berbintang didominasi oleh responden tidak menikah dan mereka termasuk kedalam wisatawan milenial yang memilki motivasi secara intrinsik di dorong oleh rasa ingin tahu dan mendapatkan pengalaman atas aktivitas yang dilakukan. Sedangkan secara ekstrinsik didorong bahwa hotel yang tersebar di Kabupaten Badung menunjukkan akses yang strategis untuk dikunjungi.

\section{Ucapan Terima kasih}

Terima kasih kami ucapkan kepada semua pihak yang telah membantu dalam penyusunan laporan ini antara lain pihak hotel yang sudah berpartisipasi, Dekan Fakultas Pariwisata, Ketua LP2M Universitas Udayana.

\section{DAFTAR PUSTAKA}

J. Supranto. 2006. Pengukuran Tingkat Kepuasan

Nyoman S,Pendit. 2002. Ilmu Pariwisata Sebuah Pengantar. Jakarta. PT. Pradnya Paramita

Sugiono. 2004. Metode Penelitian. Bandung. CV. Alfabeta

-- 2006. Statistik untuk Penelitian. Bandung. CV. Alfabeta

Wiyasa. 1997. Hotel Ramah Lingkungan Alternatif Hotel Masa Depan. Kelola No.16 TahunVI. BPFE. UGM 